\title{
A Hydro PV Hybrid System as a New Concept for an Abandoned Dam in Southern Brazil ${ }^{*}$
}

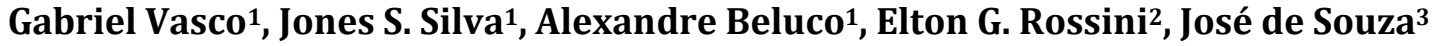 \\ ${ }^{1}$ Instituto de Pesquisas Hidráulicas, Universidade Federal do Rio Grande do Sul, Porto Alegre, Brazil \\ ${ }^{2}$ Universidade Estadual do Rio Grande do Sul, Porto Alegre, Brazil \\ ${ }^{3}$ Fundação Liberato Salzano Vieira da Cunha, Novo Hamburgo, Brazil \\ Email: albeluco@iph.ufrgs.br
}

How to cite this paper: Vasco, G., Silva, J.S., Beluco, A., Rossini, E.G. and de Souza, J. (2019) A Hydro PV Hybrid System as a New Concept for an Abandoned Dam in Southern Brazil. Computational Water, Energy, and Environmental Engineering, 8, 41-56.

https://doi.org/10.4236/cweee.2019.82003

Received: December 6, 2018

Accepted: March 19, 2019

Published: March 22, 2019

Copyright $\odot 2019$ by author(s) and Scientific Research Publishing Inc. This work is licensed under the Creative Commons Attribution International License (CC BY 4.0).

http://creativecommons.org/licenses/by/4.0/

\begin{abstract}
The search for alternatives to traditional sources of electric energy opens the way for a new market in the world, and for Brazil in particular. Still in its first steps, but with immense potential, the generation of energy from solar irradiation and hydroelectric plants in hybrid systems is an important alternative. On the other hand, single source power systems, when designed to meet a particular demand without fail, lead to low market acceptance due to the availability of resources and low efficiency in performance that rewards high initial investment costs. One solution to balance and optimize energy supply is the use of more than one energy resource when sources can be complementary. Among several possible combinations reported in several studies, the hybrid photovoltaic hydroelectric system is considered to be an optimal and interesting combination. In this context, the present article makes a technical and economic pre-feasibility analysis of a hydroelectric photovoltaic hybrid system, operating photovoltaic panels on floating structures on the water surface to allow the use of the Laranjeiras dam. The study was conducted based on simulations with HOMER. The solution indicated as optimal was the installation of a hybrid energy system, implementing a hydroelectric power plant at the base of the dam, with $1497 \mathrm{~kW}$ of installed capacity, operating simultaneously with a set of photovoltaic modules, on the water surface of the dam, with $180 \mathrm{~kW}$ of installed capacity, and a power limit for the purchase and sale to the grid equal to $400 \mathrm{~kW}$, to supply the demand of consumer loads up to $40 \mathrm{MWh}$ per day. This combination would result in an initial cost of US $\$ 3984.885$ per $\mathrm{kW}$ and an energy cost of US $\$ 0.026$ per $\mathrm{kWh}$.
\end{abstract}

\section{Keywords}

Hybrid Systems, Energetic Complementarity, PV Modules on Floating Structures, Pre-Feasibility Study, Software Homer

\footnotetext{
*Some results of this article were published earlier in the conference.
} 


\section{Introduction}

The growing demand for electricity is due to the expectation of quality in supply and the dynamics of development as a response to population growth. The constant increase in the consumption of electric energy has made the companies that generate electricity to think of different ways to increase the generation [1]. Therefore, in order to increase the share of energy to meet this demand, studies on renewable energy sources that can emit low volumes of pollutants and greenhouse gases have been studied worldwide in both laboratories and under realistic conditions that do not compromise the environment.

In addition to the already explored energy potentials, Ref. [1] mentions the need for Brazil to increase its installed capacity, through the launching of new power plants but also with other alternatives, such as the repowering of old power plants. The plants to be repowered may be in locations where the available potential has not been fully exploited, for various reasons. The investments in renewable resources occupy growing parts of the investments in new generating plants.

Due to intermittent effects and variability of renewable resources on generation systems based on a single renewable source, the hybrid systems appear as an alternative to improve the performance and the balance and to allow a greater optimization in the electric energy supply. In this view, the combination of water and solar resources is considered to be an interesting alternative, among the several possible combinations reported in several studies [2]-[7]. A hybrid system can still take advantage of the possible complementarity between the energy resources [8] [9] [10] [11].

A recent trend is the use of the free surface of water reservoirs for the installation of photovoltaic modules on floating structures, operating in hybrid systems with the hydroelectric plant that takes advantage of the available energy in the hydraulic structure that maintains the reservoir. The panels contribute to reduce the evaporation of water from the reservoir, blocking sunlight and also reducing algal blooms [12], also contributing to increase the generation of photovoltaic energy by reducing the temperature of the panels installed on the surface of the vessel.

A number of studies have already been developed dealing with this topic. Ref. [13] highlighted the good performance of mechanical methods, which include floating structures on the surface of reservoir water. Ferrer-Gisbert et al. [12] and Santafé [14] studied hybrid systems with floating structures on the water surface in irrigation systems in Spain. Ref. [1] studied the viability of electric power generation from the ecological discharge in the Guarita Hydropower Plant, a micro hydroelectric plant in the south of Brazil, adopting photovoltaic panels operating as floating structures on the water surface in the reservoir of the proposed hybrid system. Teixeira et al. [15] described with HOMER's help how a photovoltaic hydroelectric coupling would work, installed both in a water supply dam in southern Brazil. 
In this context, this article evaluates the technical and economic feasibility for the implementation of a hybrid photovoltaic hydroelectric system in the Laranjeiras dam, in southern Brazil. This hybrid system will be composed of a hydroelectric plant operating without flow regulation, with PV modules installed on floating structures, on the water surface of the reservoir formed by the dam. The evaluation will be performed with the well-known software Homer. This article is composed of four more sections besides this Introduction. The next section presents the Laranjeiras dam. The following section briefly describes the software and describes the simulations performed and the subsequent section presents and discusses the results. The last section presents the conclusions.

\section{Laranjeiras Dam}

Located in the city of Canela, a Brazilian municipality of the State of Rio Grande do Sul, the southernmost State of Brazil, in the Metropolitan Meso-region of Porto Alegre and in the Gramado Microregion, between the following geographic coordinates: latitude of $29^{\circ} 22^{\prime} 0^{\prime \prime} \mathrm{S}$ and longitude of $50^{\circ} 39^{\prime} 30^{\prime \prime} \mathrm{W}$, the Laranjeiras dam was built in the $60^{\prime}$ 's to generate electric energy, but the project was not finalized, having been transformed into a tourist attraction, used for rafting. The region of the dam, shown in Figure 1, can be seen on Google Maps on http://goo.gl/maps/E8WuBzWMmpv. The project lost its viability originally designed for a power output of $7 \mathrm{MW}$, due to the economic changes experienced by Brazil over the years of its construction.

The Laranjeiras hydropower plant, located on the Paranhana River and not completed, would be the third stage of the Salto System, also using waters diverted from the Santa Maria River (Currently, Brazilian environmental legislation imposes many obstacles to the approval of such projects). The original project considered the construction of a channel with $5900 \mathrm{~m}$ of extension to an engine room, using a total height of about 100 meters. The original design envisaged about 7.5 MW, with channel and pipe designed for $10 \mathrm{~m}^{3} / \mathrm{s}$, starting at the water intake in the dam and extending to the engine room [16].

Figure 2 shows the dam spillway and Figure 3 shows the reservoir near the dam. The dam is 280 meters long, 12 meters high. The reservoir formed by the dam is about $2 \mathrm{~km}$ long, with depths between 10 meters near the dam and 3 meters at the other end, with capacity of $200,000 \mathrm{~m}^{3}$. In the original project, carried out by the extinct DNOS (National Department of Works and Sanitation), for the construction of the Laranjeiras hydroelectric plant, it is the third stage of the Salto System (which uses the waters of the Santa Maria River), downstream of the Bugres and Canastra, already in operation. The Laranjeiras reservoir is fed with the discharge flow of the Canastra hydro power plant [16].

According to the Koppen climate classification, the region presents two climatic types: Cfa (mesothermal, humid subtropical without dry season, minimum average temperature of $18^{\circ} \mathrm{C}$ and maximum of $22^{\circ} \mathrm{C}$ ) and $\mathrm{Cfb}$ (mesothermal, humid temperate, $22^{\circ} \mathrm{C}$ ). Precipitations are well distributed throughout the 
year, with a mean of $2310 \mathrm{~mm}$ for a station located in the upper portion of the Paranhana river basin and $1401 \mathrm{~mm}$ in a position in the lower portion of the basin. The average temperatures in the region are respectively $19.4^{\circ} \mathrm{C}$ and $14.4^{\circ} \mathrm{C}$ in these two regions, with relative humidity of $80 \%$, with little variation [17].

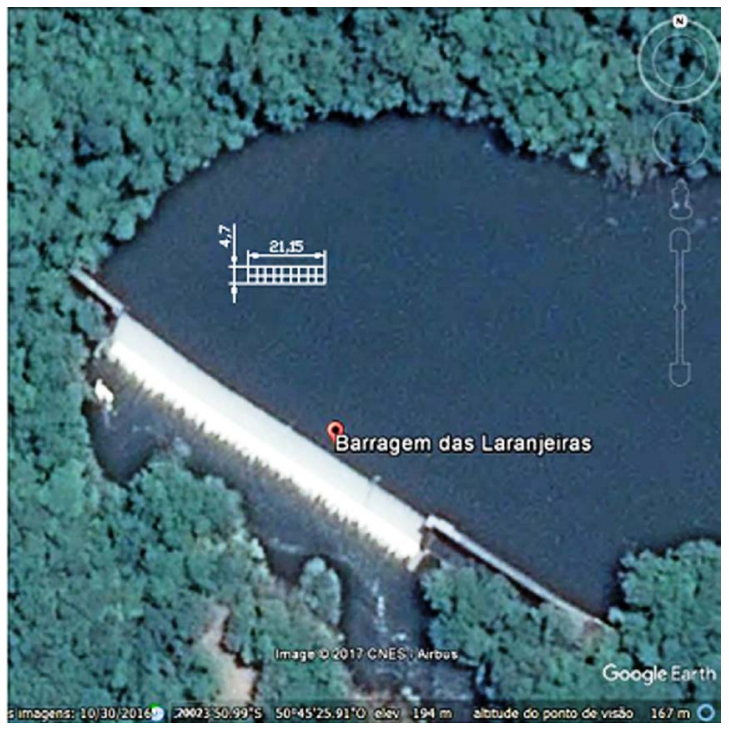

Figure 1. Image of the Laranjeiras Dam and comparison of the dimensions of the PV panels placed on floating structures with the region near the dam.

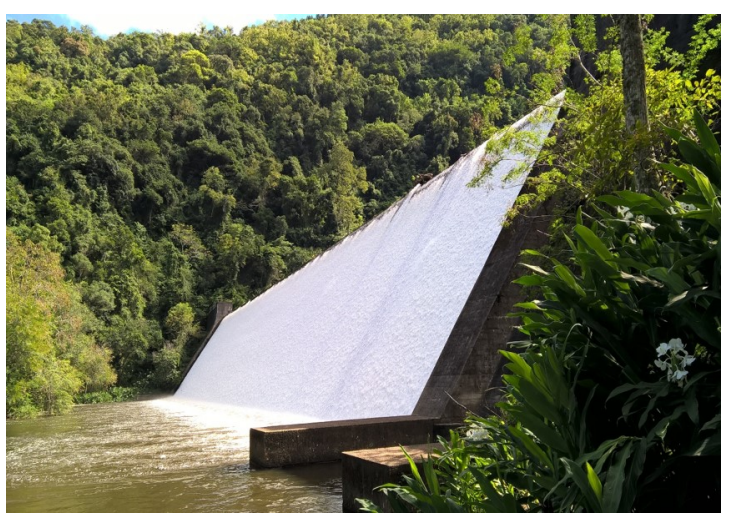

Figure 2. Lateral view of the Laranjeiras dam spillway.

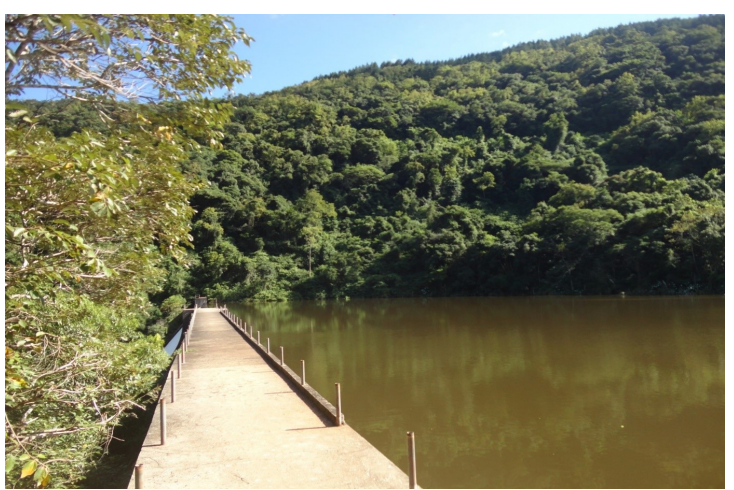

Figure 3. View of the water surface near the Laranjeiras dam. 
The review of the original project of the Laranjeiras hydroelectric plant determined two solutions: the implementation of a hydroelectric plant aiming operation as a base plant, and another considering the operation at peak times [16]. These two solutions envisaged a channel with $5900 \mathrm{~m}$, a forced conduit of about $500 \mathrm{~m}$ in length, for a static fall of $100 \mathrm{~m}$ and a machine room restoring waters to the Paranhana river. This article suggests a hydroelectric power plant with a new conception, with a machine house located near the base of the dam, providing energy supply with much lower power.

\section{Simulations with Homer and the Proposed System}

Homer software [18] [19] is a well-known software for simulation of small-scale power generation systems, proving itself over the years very suitable [20] for the simulation of hybrid systems. Homer simulates one year of system operation and performs an economic appraisal for the established lifetime of the project. Homer selects the values of optimization variables appropriate for the optimum solutions, those that reduce the total value of the net present cost considering the lifetime of the project. In addition, Homer allows a sensitivity analysis from selected variables for the study.

For this study, the simulations were performed for a 25 -year operating period, with $12 \%$ annual interest and $6 \%$ internal rate of return. The US dollar was adopted for all components costs, due to a good availability of information, as well as allowing an evaluation less subject to issues related to instabilities typical of Brazilian economic and financial reality. Figure 4 shows a schematic diagram of the hydro PV hybrid system proposed in this study for operation at the Laranjeiras dam and simulated with Homer.

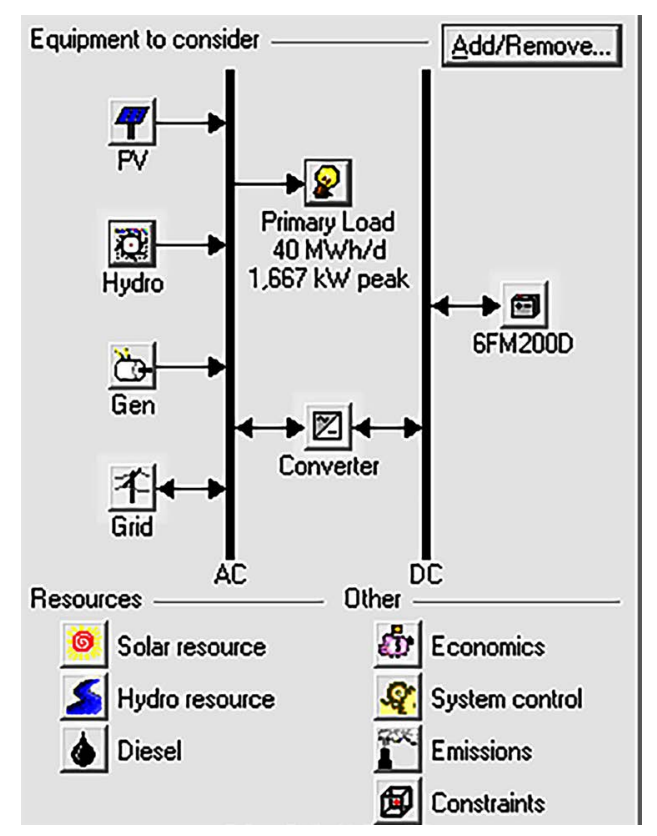

Figure 4. Schematic diagram of the hydro PV hybrid system proposed in this study. 
The proposed system is composed of a hydroelectric plant and photovoltaic modules, which appear in the upper left corner of Figure 4. The system also has a diesel generator set and a battery bank as alternatives to supply power in moments of possible low availability of renewable resources. In addition, the system also simulates connection to the grid, to contribute power to the interconnected system operating permanently and not just at peak times. The load to be served is $40 \mathrm{MWh}$ per day, with a peak power of $1667 \mathrm{~kW}$, obtained after some simulations as the most adequate considering the dimensions of the hydroelectric plant that can operate with the engine room installed near the dam base.

Regarding the hydroelectric power plant, as a reference, the total costs of remodeling a project, including the purchase and installation of components, were estimated in 2010 to be in the range of US $\$ 500.00$ per $\mathrm{kW}$ to US $\$ 1000.00$ per $\mathrm{kW}$ installed in Brazil [21]. According to Braciani [22], the average cost per kilowatt installed for a hydropower plant with reservoir flow regulation in Brazil is about US $\$ 1324.00$ per $\mathrm{kW}$, with approximately $45 \%$ of this cost corresponding to civil works.

In this study, the costs of the hydroelectric plant are considered as a sensitivity variable, allowing the analysis of its influence on the viability of the project. The capital cost as sensitivity variable was included in the simulations with values of US $\$ 750000.00 / \mathrm{kW}$, US $\$ 900000.00 / \mathrm{kW}$, US $\$ 1050000.00 / \mathrm{kW}$. The replacement cost the equipment at the end of its useful life was considered equal to $80 \%$ of the capital cost, US\$600000.00/kW, US $\$ 720000.00 / \mathrm{kW}$, US $\$ 840000.00 / \mathrm{kW}$. The annual cost of operation and maintenance has a typical value of $4 \%$ of the capital cost [21], resulting in values of US $\$ 37500.00 / \mathrm{kW}$, US $\$ 45000.00 / \mathrm{kW}$, US $\$ 52500.00 / \mathrm{kW}$. The replacement cost and operation and maintenance cost are linked to the capital cost for the simulations. Life time was considered as 25 years.

During the study, no data were found allowing to know the available flow in the section of the dam. As this study was performed at the pre-feasibility level, the available flow rate for the proposed plant was determined indirectly. The available flow for a plant installed at the base of the Laranjeiras dam was then evaluated from the flows discharged by the hydroelectric plant installed immediately downstream, which is the Canastra Plant. There is, however, a small tributary that contributes about ten per cent of the flow that reaches the Laranjeiras dam and has not been the subject of a specific study. Thus, the simulations were carried out with the flow with a sensitivity variable, to study the effect of this tributary on the flow available for power generation.

The simulations were performed for a series of flow data discharged by the Canastra Power Plant during the year 2015 provided by the State Electric Power Company [23]. Figure 5(a) shows the maximum, average and minimum monthly values for this series and Figure 5(b) shows the hourly variation of the values for this series. The maximum flow values occur in September and October, while the minimum value occurs in March. The graph in (b) allows to evaluate the monthly variability of the flows, smaller when the color variation is smaller and bigger when this variation is greater. 


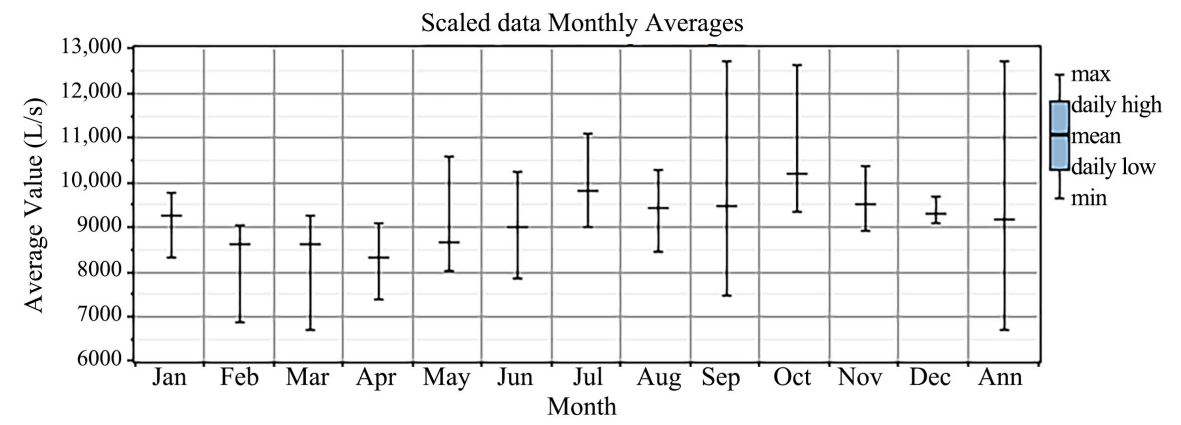

(a)

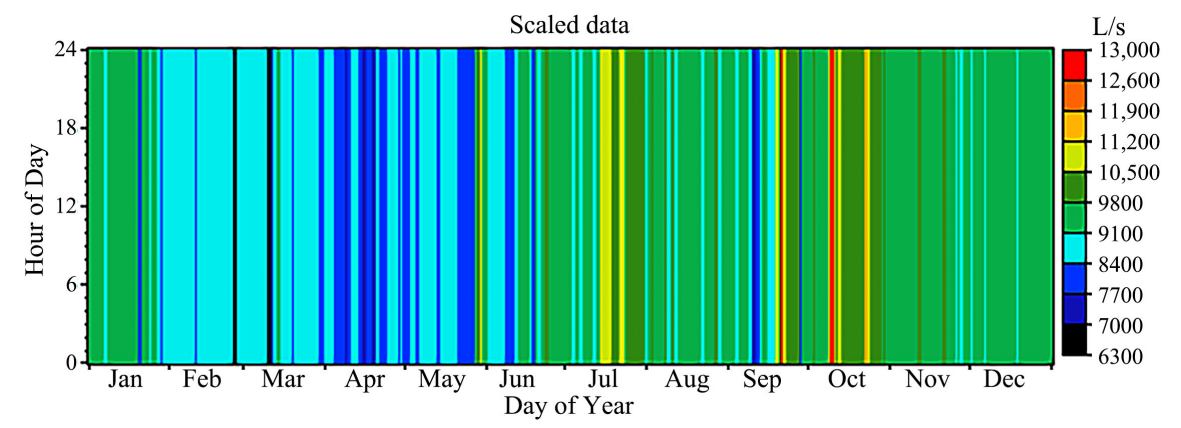

(b)

Figure 5. Flow discharged by the Canastra Hydroelectric Power Plant. Above, monthly minimum, average and maximum values; below, the hourly distribution of the values throughout the year.

The engine room of the hydroelectric plant will be located at the foot of the dam, obeying the topography of the terrain. The height is 20 meters and the average annual flow to be boosted is 9000 liters per second. The nominal power of the proposed plant is then $1497 \mathrm{~kW}$, considering a final efficiency of $80 \%$. The simulations were carried out with sensitivity values for the turbine flow of $9900 \mathrm{~L} / \mathrm{s}$ and $10,800 \mathrm{~L} / \mathrm{s}$, corresponding to $110 \%$ and $120 \%$ of the nominal value to be used for power generation.

The consumer load to be served by the hybrid system proposed in this study was largely based on the installed capacity of the hydropower plant. A guarantee to supply the energy to this load (considering the simulations with the Homer) is the connection to the grid. The power supplied by the grid will comply with the values determined by the National Electric Energy Agency [24], costing US $\$ 0.10 / \mathrm{kWh}$ outside peak and US $\$ 0.50 / \mathrm{kWh}$ at peak hours, with sales at US $\$ 0.08 / \mathrm{kWh}$ out of peak and US $\$ 0.25 / \mathrm{kWh}$ during peaks.

Regarding the PV modules, the size of the system to be mounted on floating structures was considered as an optimization variable, with values of $0 \mathrm{~kW}, 180$ $\mathrm{kW}, 360 \mathrm{~kW}, 540 \mathrm{~kW}, 720 \mathrm{~kW}, 900 \mathrm{~kW}, 1080 \mathrm{~kW}, 1260 \mathrm{~kW}$ and $1440 \mathrm{~kW}$. The capital cost was considered equal to US $\$ 3200 / \mathrm{kW}$ and an useful life of 12.5 years [1]. The replacement costs were considered equal to $80 \%$ and the annual costs of operation and maintenance were considered equal to $5 \%$ of capital cost, both linked with the capital cost.

The floating structures add about 30\% [12] [13] [14] to the total cost of instal- 
ling the photovoltaic panels in the desired configuration in this study. The costs of the modules were considered as a sensitivity variable with the values 1.00 , $0.50,0.25,0.15,0.10,0.05$ and 0.01 . These values multiply the costs of the photovoltaic system, allowing to verify both the influence of these $30 \%$ of cost increase with the floating system and the influence of cost reductions of photovoltaic panels on the feasibility of the project.

Figure 1 shows a small drawing superimposed on the image collected in Google Maps. A small checkerboard in white lines, placed closer to the left jamb of the dam. This design shows the probable dimensions of a photovoltaic system with 18 floating structures with a capacity of $30 \mathrm{~kW}$ each, occupying a small area compared to the region of the reservoir near the dam. The region is clouded during a few hours of the day during a reasonable part of the year and the possibility of covering a much larger area or even covering the entire surface of the reservoir in the region near the dam was not considered.

The incident solar radiation and atmospheric transparency data at the dam site were automatically obtained by Homer in a NASA database [18]. Figure 6(a) shows the maximum, average and minimum monthly values of solar radiation incident on a horizontal plane and Figure 6(b) shows the hourly variation of incident solar radiation over 365 days of the year. It can be clearly seen in the graph in (b) that summer and spring are the seasons with the highest incidence of solar radiation, whereas autumn and winter are the seasons with the lowest incidence of solar radiation. The dark zone of the diagram (black color) indicates, to a large extent, the absence of solar radiation, that is, the night time period. The graph in (b) shows the variation of the incident solar radiation throughout the year and the variation of the duration of days throughout the year.

The components of the hybrid system are interconnected by the AC bus, responsible for providing a constant amount of electricity to the grid. In this study, converters performing the functions of inverters and rectifiers with $100 \%$ of the total capacity, with efficiency of $85 \%$ as an inverter and $90 \%$ as a rectifier, were considered. The service life of these devices has been estimated at 12.5 years. The cost of these devices was valued at US $\$ 400$ per $\mathrm{kW}$. The converters allow the storage of energy in the batteries, transferring power from the AC to the DC bus when there is energy left and in the opposite direction when the available energy is not enough to meet the demand.

The simulations were performed for the following optimization variables: 0 $\mathrm{kW}, 180 \mathrm{~kW}, 360 \mathrm{~kW}, 540 \mathrm{~kW}, 720 \mathrm{~kW}, 900 \mathrm{~kW}, 1080 \mathrm{~kW}, 1260 \mathrm{~kW}$ and 1440 $\mathrm{kW}$ for capital cost of photovoltaic modules; $0 \mathrm{~kW}, 12.5 \mathrm{~kW}$ and $25 \mathrm{~kW}$ for the capacity of the diesel generator system; 0,60 and 120 batteries; $0 \mathrm{~kW}, 30 \mathrm{~kW}$ and $60 \mathrm{~kW}$ for the converter capacity; $0 \mathrm{~kW}, 200 \mathrm{~kW}$ and $400 \mathrm{~kW}$ for the power capacity of the connection to the grid. The simulations were performed for the following values for the sensitivity variables: 30,000 MWh per day, 35,000 MWh per day and $4000 \mathrm{MWh}$ per day for the load to be served; $0 \mathrm{~kW}, 200 \mathrm{~kW}$ and 400 $\mathrm{kW}$ for the network's ability to purchase surplus energy; and US $\$ 0.60$ per liter; US $\$ 0.70$ per liter; US $\$ 0.80$ per liter and US $\$ 0.90$ per liter of diesel. 


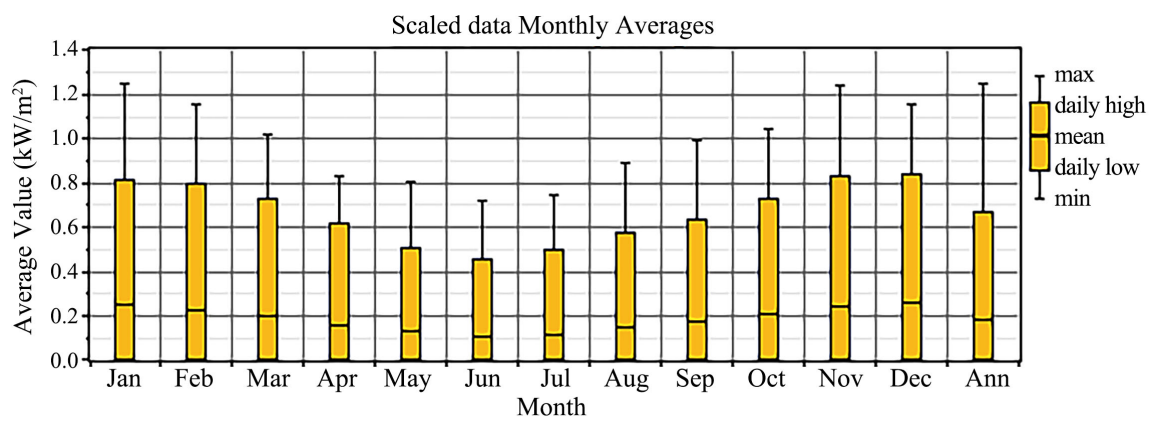

(a)

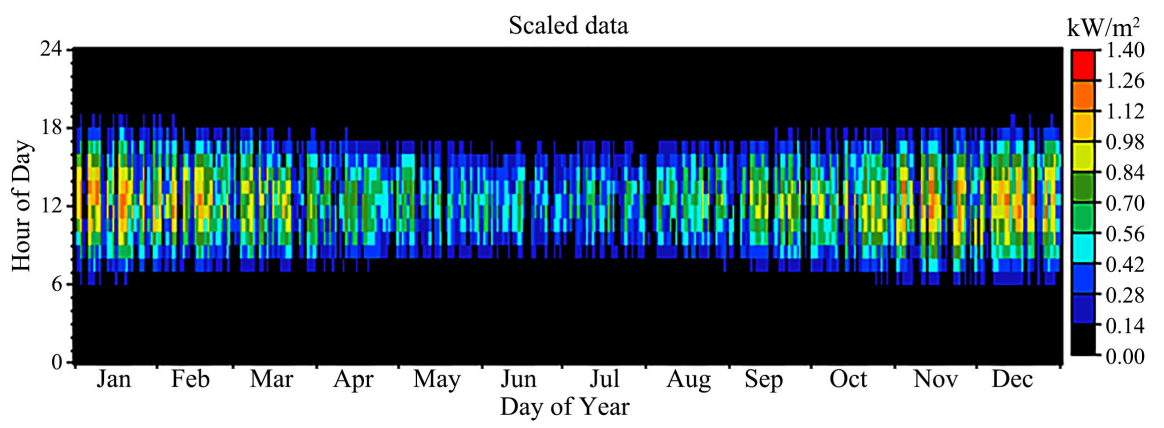

(b)

Figure 6. Solar radiation incident on a horizontal plane, obtained with HOMER, for the location of the Laranjeiras Dam. Power Plant. Above, monthly minimum, average and maximum values; below, the hourly distribution of the values throughout the year.

\section{Results and Discussion}

The results of the simulations indicate that this pre-feasibility study should indicate the installation of a hydroelectric power plant at the base of the dam with $1497 \mathrm{~kW}$ installed power, with PV panels installed on floating structures on the surface of the reservoir, with a power of $180 \mathrm{~kW}$, supplying a constant load of 40 MWh per day.

Figure 7 shows the optimal results provided by Homer, ranked in ascending order for the total NPC value. The first of the two solutions appearing is the optimum solution described above. Figure 8 shows the optimization space for the initial cost of the hydroelectric plant [US\$/kW] as a function of the consumer loads demand per day [kWh/d], with the power of the PV modules superimposed on the graph, for a flow rate of $9171 \mathrm{~L} / \mathrm{s}$ and the possibility of sale and purchase of $400 \mathrm{~kW}$ to the grid.

The two solutions of Figure 7 present practically the same cost of energy. The difference is only in the bank of 120 batteries included in the second solution, representing a total cost that is diluted throughout the 25 years of operation of the system. The main consequence of the inclusion of this battery bank is a very small increase in the energy fraction that comes from renewable sources, from $90.2 \%$ to $90.3 \%$.

The optimization space of Figure 8 shows that the limit for use of the hydroelectric power plant in a system with connection to the grid is the supply of a load 
of $35 \mathrm{MWh}$ per day. The addition of photovoltaic panels to the hybrid system allows the supply of $40 \mathrm{MWh}$ per day. The simulations were limited to $40 \mathrm{MWh}$ per day because higher values of demand to be met resulted in non-viable solutions.

The question of the area of the optimization space that corresponds to feasible solutions containing photovoltaic panels leads to ask for the feasibility limits considering the capital cost of the photovoltaic panels. Programs to encourage the repowering of abandoned or unfinished plants may favor the acquisition of photovoltaic panels with values lower than those that have been practiced commercially. Figure 9 and Figure 10 show the optimization spaces for the cost of the hydropower plant [US $\$ / \mathrm{kW}]$ as a function of the demand per day $[\mathrm{kWh} / \mathrm{d}]$, with the power of the PV modules superimposed on the graph, for a flow rate of $9171 \mathrm{~L} / \mathrm{s}$ and the possibility of sale and purchase of $400 \mathrm{~kW}$ to the grid, with PV panels with capital cost respectively $25 \%$ and $15 \%$ of the current cost.

The results with $25 \%$ of the current capital cost (Figure 9) indicate a small increase in the area corresponding to the solutions including photovoltaic panels (in yellow), but with a considerable increase in the installed power for the demand of $40 \mathrm{MWh}$ per day, that goes from $180 \mathrm{~kW}$ to $540 \mathrm{~kW}$ (and with $180 \mathrm{~kW}$ to $35 \mathrm{MWh}$ per day).

\begin{tabular}{|c|c|c|c|c|c|c|c|c|c|c|c|}
\hline Sensitivity Results & \multicolumn{11}{|c|}{ Optimization Results } \\
\hline \multicolumn{12}{|c|}{ Sensitivity variables - } \\
\hline \multicolumn{3}{|c|}{ Primary Load (kWh/d) $40,000 \nabla$} & \multicolumn{3}{|c|}{ Stream Flow $( \mathrm { L } / \mathrm { s } ) \longdiv { 9 . 1 7 1 \quad \nabla }$} & \multicolumn{2}{|c|}{ 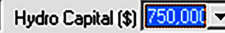 } & \multicolumn{3}{|c|}{ Grid Sale Capacity $( \mathrm { kW } ) \longdiv { 4 0 0 \quad }$} & \multirow{2}{*}{ Details... } \\
\hline \multicolumn{8}{|c|}{ Double click on a system below for simulation results. } & \multicolumn{2}{|c|}{ Categonized $C$ Overall } & Export... & \\
\hline 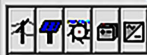 & $\begin{array}{c}\mathrm{PV} \\
\mathrm{kW}) \\
\end{array}$ & $\begin{array}{l}\text { Hydro } \\
(\mathrm{kW})\end{array}$ & 6FM2000 & $\begin{array}{l}\text { Conv. } \\
\text { (kW) }\end{array}$ & $\begin{array}{l}\text { Gind } \\
(\mathrm{kW})\end{array}$ & $\begin{array}{l}\text { Initial } \\
\text { Capital }\end{array}$ & \begin{tabular}{l|} 
Operating \\
Cost $(S / y \pi)$
\end{tabular} & $\begin{array}{l}\text { Total } \\
\text { NPC } \\
\end{array}$ & \begin{tabular}{|c|}
$\mathrm{COE}$ \\
$(\mathrm{S} / \mathrm{kWh})$
\end{tabular} & \begin{tabular}{|l|l} 
Ren. \\
Frac. \\
\end{tabular} & \\
\hline 仵策 & 180 & 1497 & & & 400 & \$ 1.154 .480 & 265.149 & \$ 3.984.885 & 0.026 & 0.90 & \\
\hline 平筷国图 & 180 & 1497 & 120 & 30 & 400 & \$ 1.202 .480 & 267.449 & $\$ 4.057 .435$ & 0.026 & 0.90 & \\
\hline
\end{tabular}

Figure 7. Optimal results obtained by Homer, classified based on the total NPC.

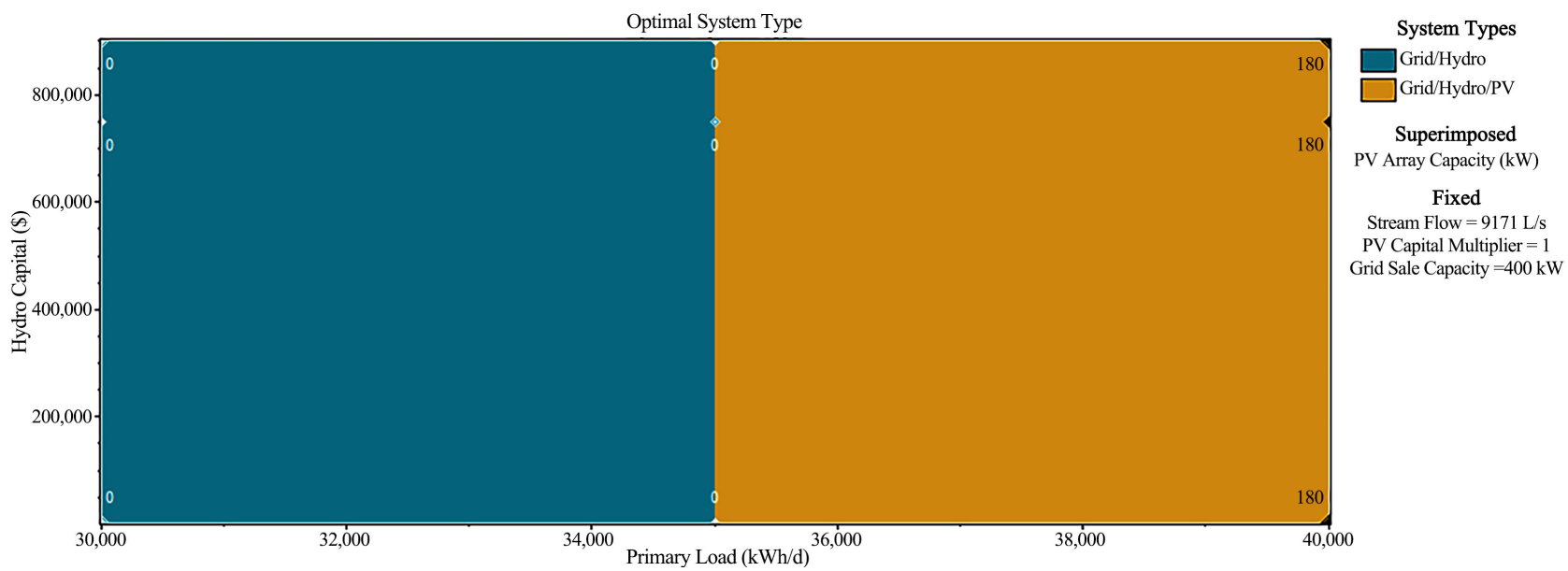

Figure 8. Optimization space for the initial cost of the hydroelectric [US\$/kW] as a function of the consumer loads demand per day $[\mathrm{kWh} / \mathrm{d}]$, with the power of the PV modules superimposed on the graph, for a flow rate of $9171 \mathrm{~L} / \mathrm{s}$ andthe possibility of sale and purchase of $400 \mathrm{~kW}$ to the grid. 


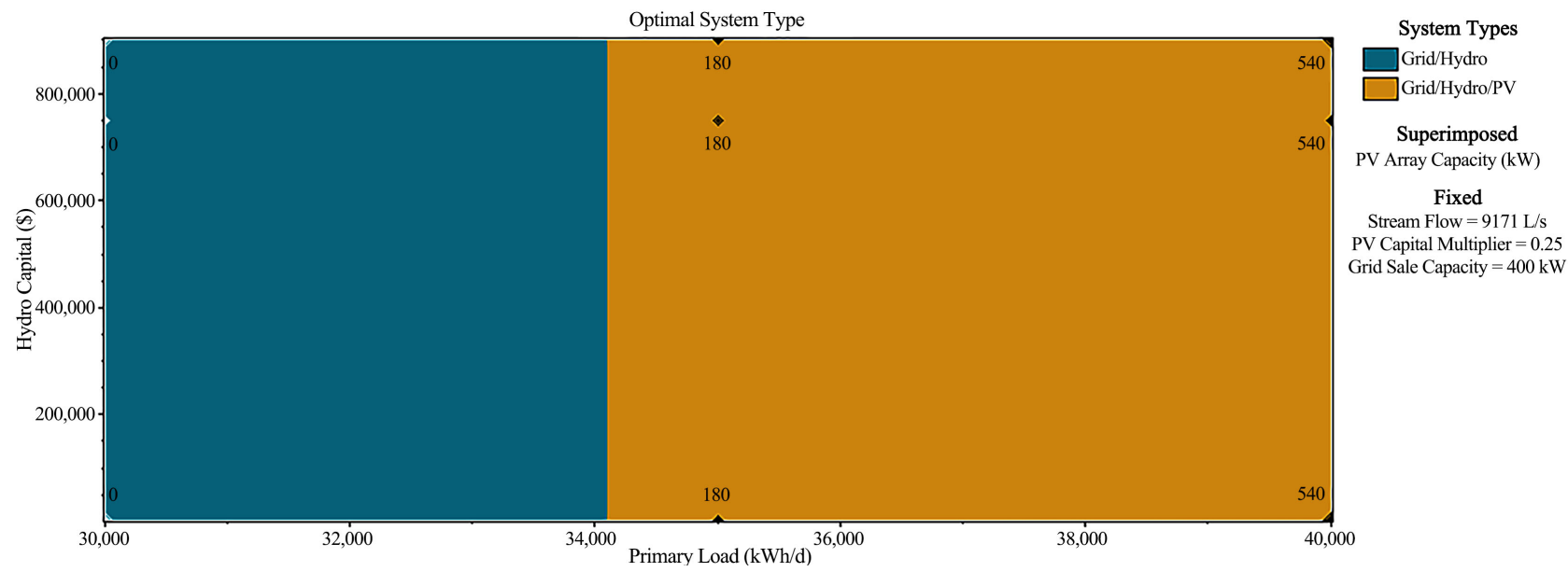

Figure 9. Optimization space for the initial cost of the hydroelectric [US\$/kW] as a function of the consumer loads demand per day $[\mathrm{kWh} / \mathrm{d}]$, with the power of the PV modules superimposed on the graph, for a flow rate of $9171 \mathrm{~L} / \mathrm{s}$ andthe possibility of sale and purchase of $400 \mathrm{~kW}$ to the grid, with photovoltaic panels with capital cost $25 \%$ of the current cost.

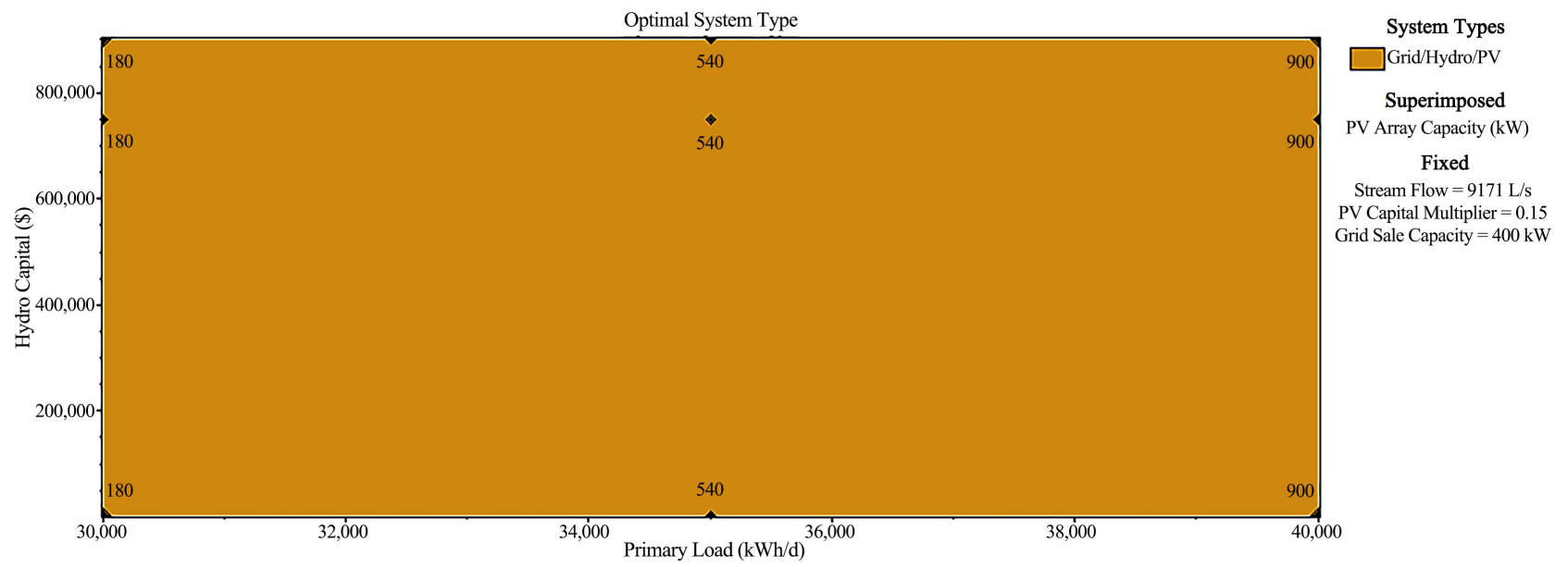

Figure 10. Optimization space for the initial cost of the hydroelectric [US $\$ \mathrm{~kW}$ ] as a function of the consumer loads demand per day $[\mathrm{kWh} / \mathrm{d}]$, with the power of the PV modules superimposed on the graph, for a flow rate of $9171 \mathrm{~L} / \mathrm{s}$ andthe possibility of sale and purchase of $400 \mathrm{~kW}$ to the grid, with photovoltaic panels with capital cost $25 \%$ of the current cost.

The results with $15 \%$ of the current capital cost (Figure 10) indicate a large increase in the area corresponding to the solutions including PV panels (in yellow), with a very large increase in the installed power for the demand of $40 \mathrm{MWh}$ per day, going from $180 \mathrm{~kW}$ and $540 \mathrm{~kW}$ o $900 \mathrm{~kW}$. The results indicated that for a capital cost of $1 \%$ of the current cost, the optimal solutions would contain PV panels totaling $1440 \mathrm{~kW}$.

Power generation with a $10 \%$ higher flow rate than $9171 \mathrm{~L} / \mathrm{s}$ (using water from the tributary contributing to the reservoir) leads to optimal solutions not including photovoltaic panels and reduces energy costs to US $\$ 0.012$ per $\mathrm{kW}$. Power generation with a $20 \%$ higher flow rate, eventually available in years with above-average rainfall, also leads to optimum solutions not including photovoltaic panels and reduce energy costs to $\$ 0.004$ per $\mathrm{kW}$, mainly by selling surplus energy to the grid. 
The results shown in these figures were obtained with capital cost for the hydroelectric power plant proposed in this study equal to US $\$ 750,000$ per $\mathrm{kW}$. The increase in capital cost to $\$ 900,000$ per $\mathrm{kW}$ raises the cost of energy to $\$ 0.027$ per $\mathrm{kWh}$, while the increase to $\$ 1,050,000$ per $\mathrm{kW}$ raises the cost of energy to $\$ 0.028$ per $\mathrm{kWh}$, for the results shown in Figure 8. The increase in the capital cost scenarios with photovoltaic panels with reduced costs leads to proportional increases in energy costs.

Homer was tuned for optimal solutions with zero capacity shortage. In various circumstances Homer finds optimal results with capacity shortage values close to the programmed target. The results of the simulations for this study always resulted in failures equal to $0.0989 \%$. This result indicates that the energy generated by the energy conversion devices was not sufficient to meet $0.0989 \%$ of the demand of the consumer loads.

Failures to meet consumer demands may occur with an occasional amount of power available from generators that are less than the power demanded by consumers. Stored energy, depending on the storage device, can be employed to avoid failures.

Figure 11 shows two graphs: above, the state of charge of the batteries, and below, AC power, PV power and hydro power over a year for the best optimal solution of the two solutions appearing in Figure 7. In turn, Figure 12 also shows two graphs: above, the state of charge of the batteries, and below, AC power, PV power and hydro power over a year for an optimal solution equivalent to the solution shown in Figure 11 but equipped with photovoltaic panels presenting capital costs equal to $15 \%$ of the current capital cost.

The state of charge of the battery bank in Figure 11 is modulated mainly by the variations observed in the water availability, which corresponds to most of the energy available in that system. The lower power installed in photovoltaic modules naturally causes the PV contribution to this system to be much lower. In turn, the state of charge of the battery bank in Figure 12 is modulated by the variations observed in the availability of solar energy. The higher installed power in photovoltaic modules, comparing with the system of Figure 11, makes the photovoltaic contribution decisively influence this system, due to the high intermittence of this energy alternative.

\section{Conclusions}

This paper presents the main results of a pre-feasibility study of a hydroelectric photovoltaic hybrid system for the repowering of the Laranjeiras dam, in southern Brazil. The optimum solution obtained with the software Homer includes a 20 meters high hydropower plant with a mean flow of 9171 liters per second to generate approximately $1497 \mathrm{~kW}$ installed at the base of the dam, operated in conjunction with $180 \mathrm{~kW}$ photovoltaic panels, and operated over floating structures on the surface of the reservoir. This system was simulated with the possibility of buying and selling $400 \mathrm{~kW}$ for the grid, supplying $40 \mathrm{MWh}$ per day, with a capital cost of US $\$ 3984885.00$ per $\mathrm{kW}$ and a cost of energy of US $\$ 0.026$ per $\mathrm{kWh}$. 


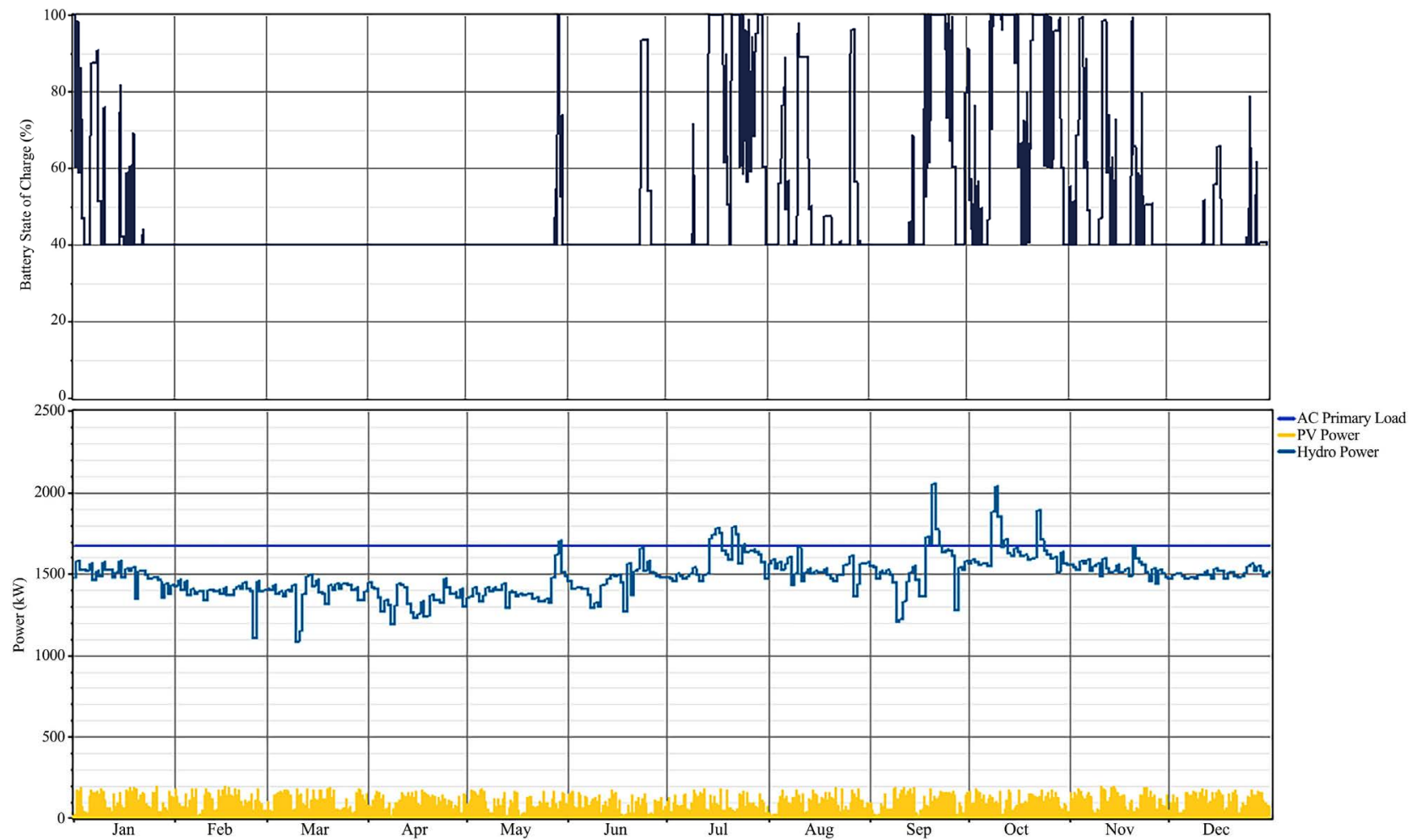

Figure 11. AC primary load, PV power and hydro power, below, state of charge of batteries, above, along one year for the first optimal solution shown in Figure 7.
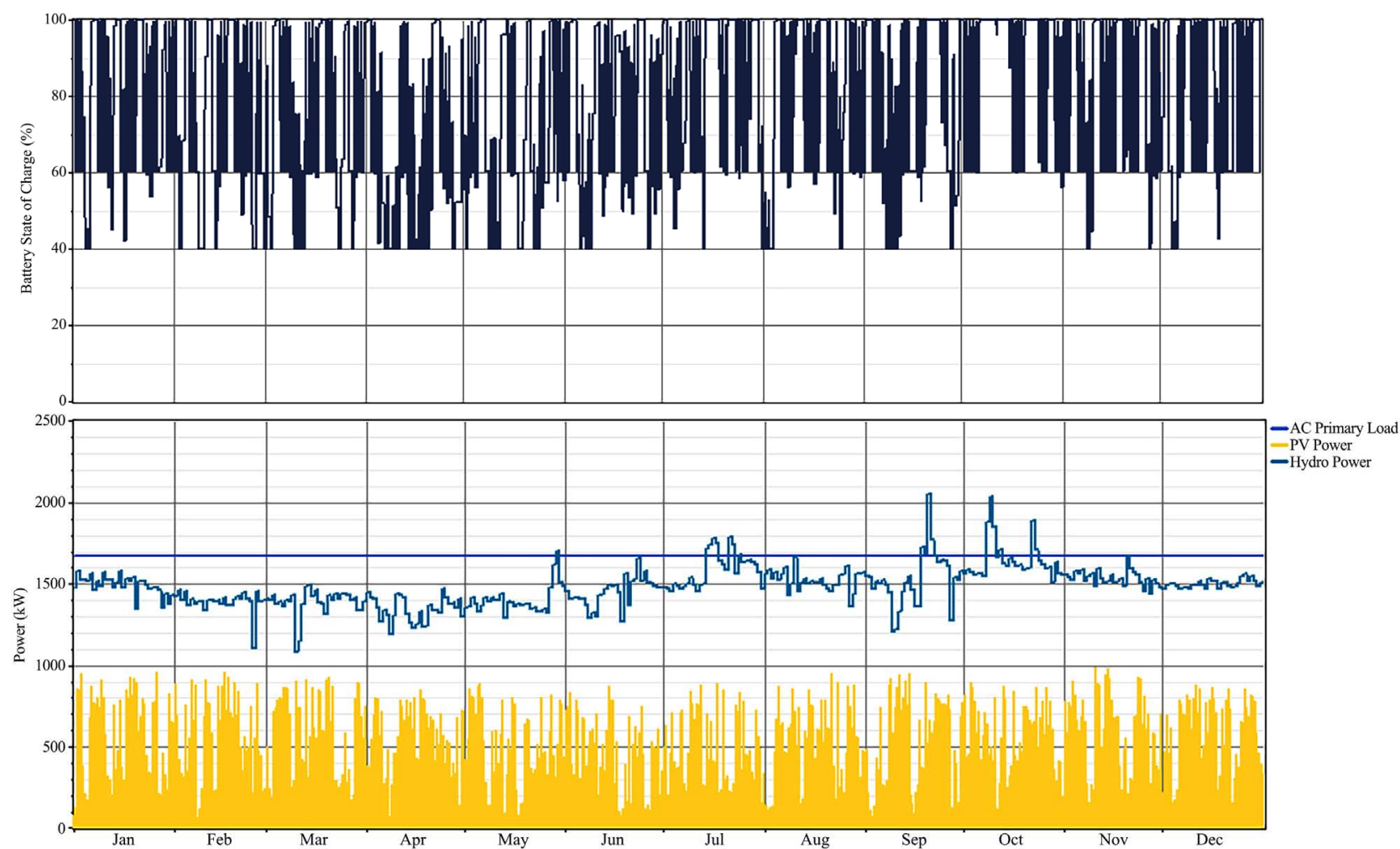

Figure 12. AC primary load, PV power and hydro power, below, state of charge of batteries, above, along one year for an optimal solution equivalent to the solution shown in Figure 11, with photovoltaic panels costing 15\% of the current capital cost. 
The Homer software also allowed to evaluate the limits of the optimum solution found and indicated that the acquisition of photovoltaic panels with advantageous prices or subject to incentives for their acquisition can lead to optimum solutions with much greater contributions of photovoltaic energy. PV panels purchased for $25 \%$ of the current capital cost can lead to optimal solutions with $540 \mathrm{~kW}$ of photovoltaic power. Panels purchased for $15 \%$ of the current capital cost can reach $900 \mathrm{~kW}$ of photovoltaic power in the proposed hydro PV hybrid system.

\section{Acknowledgements}

This work was developed as a part of the activities of the Research Group on Renewable Energies and Sustainability of the Instituto de Pesquisas Hidráulicas, Universidade Federal do Rio Grande do Sul, in southern Brazil. The authors acknowledge the support received by the institution. The first author is grateful for the support received from the Post-Graduation Students Program (PEC-PG), from CAPES/CNPq/MRE-Brasil. The third author acknowledges the financial support received from CNPq for his research work (proc. n.312941/2017-0).

\section{Conflicts of Interest}

The authors declare no conflicts of interest regarding the publication of this paper.

\section{References}

[1] Schultz, R., Beluco, A., Homrich, R.P. and Eifler, R.C. (2016) A PV Hydro Hybrid System Using Residual Flow of Guarita Hydro Power Plant, in Southern Brazil. In: Kishor, N. and Fraile-Ardanuy, J., Eds., Modeling and Dynamic Behavior of Hydropower Plants, The Institution of Engineering and Technology, 185-202.

[2] Santarelli, M. and Macagno, S. (2004) Hydrogen as an Energy Carrier in Stand-Alone Applications Based on PV and PV Micro Hydro Systems. Energy, 29, 1159-1182. https://doi.org/10.1016/j.energy.2004.02.023

[3] Beluco, A., Souza, P.K. and Krenzinger, A. (2008) PV Hydro Hybrid Systems. IEEE Latin America Transactions, 6, 626-631. https://doi.org/10.1109/TLA.2008.4917434

[4] Nfah, E.M. and Ngundam, J.M. (2009) Feasibility of Pico Hydro and Photovoltaic Hybrid Power Systems for Remote Villages in Cameroon. Renewable Energy, 34, 1445-1450. https://doi.org/10.1016/j.renene.2008.10.019

[5] Kenfack, J., Neirac, F.P., Tatietse, T.T., Mayer, D., Fogue, M. and Lejeune, E. (2009) Micro Hydro PV Hybrid System: Sizing a Small Hydro PV Hybrid System for Rural Electrification in Developing Countries. Renewable Energy, 34, 2259-2263. https://doi.org/10.1016/j.renene.2008.12.038

[6] Muhida, R., Mostavan, A., Sujatmiko, W., Park, M. and Matsuura, K. (2001) The 10 Years Operation of a PV Micro Hydro Hybrid System in Taratak, Indonesia. Solar Energy Materials and Solar Cells, 67, 621-627. https://doi.org/10.1016/S0927-0248(00)00334-2

[7] Bekele, G. and Tadesse, G. (2012) Feasibility Study of Small Hydro PV Wind Hybrid System for Off Grid Rural Electrification in Ethiopia. Applied Energy, 97, 5-15. 
https://doi.org/10.1016/j.apenergy.2011.11.059

[8] Beluco, A., Souza, P.K. and Krenzinger, A. (2008) A Dimensionless Index Evaluating the Time Complementarity between Solar and Hydraulic Energies. Renewable Energy, 33, 2157-2165. https://doi.org/10.1016/j.renene.2008.01.019

[9] Kougias, I., Szabó, S., Monforti-Ferrario, F., Huld, T. and Bódis, K. (2016) A Methodology for Optimizaiton of the Complementarity between Small Hydropower Plants and Solar PV Systems. Renewable Energy, 87, 1023-1030. https://doi.org/10.1016/j.renene.2015.09.073

[10] During Fo., F.A., Beluco, A., Rossini, E.G. and Souza, J. (2018) Influence of Time Complementarity on Energy Storage through Batteries in Hydro PV Hybrid Energy System. Computational Water, Energy and Environmental Engineering, 7, 142-159. https://doi.org/10.4236/cweee.2018.73010

[11] Jurasz, J., Beluco, A. and Canales, F.A. (2018) The Impact of Complementarity on Power Supply Reliability of Small Scale Hybrid Energy Systems. Energy, 161, 737-743. https://doi.org/10.1016/j.energy.2018.07.182

[12] Ferrer-Gisbert, C.M., Ferran-Gozalvez, J.J., Santafe, M.R., Ferrer-Gisbert, P., Sanchez-Romero, F.J. and Torregrose-Soler, J.B. (2013) A New Photovoltaic Floating Cover System for Water Reservoirs. Renewable Energy, 60, 63-70. https://doi.org/10.1016/j.renene.2013.04.007

[13] Craig, I., Green, A., Scobie, M. and Schmidt, E. (2005) Controlling Evaporation Loss from Water Storages. NCEA Publication $\mathrm{N}^{\circ} 1000580 / 1,207 \mathrm{p}$.

[14] Santafe, M.R., Ferrer-Gisbert, P.S., Sanchez-Romero, F.J., Torregrose-Soler, J.B., Ferran-Gozalvez, J.J. and Ferrer-Gisbert, C.M. (2014) Implementation of a Photovoltaic Floating Cover for Irrigation Reservoirs. Journal of Cleaner Production, 66, 568-570. https://doi.org/10.1016/j.jclepro.2013.11.006

[15] Teixeira, L.E., Caux, J., Beluco, A., Bertoldo, I., Louzada, J.A.S. and Eifler, R.C. (2015) Feasibility Study of a Hydro PV Hybrid System Operating at a Dam for Water Supply in Southern Brazil. Journal of Power and Energy Engineering, 3, 70-83. https://doi.org/10.4236/jpee.2015.39006

[16] CEEE Companhia Estadual de Energia Elétrica (State Electric Energy Company) (1970) Re-Evaluation of the Design of Laranjeiras Hydropower Plant. ELC: Electroconsult, São Paulo. (In Portuguese)

[17] Engenharia, M. (1996) Simulation of a Management Proposal for the Sinos Basin. Final Report, GovernmentofStateof Rio Grande do Sul, Porto Alegre. (In Portuguese)

[18] Lambert, T.W., Gilman, P. and Lilienthal, P.D. (2005) Micropower System Modeling with Homer. In: Farret, F.A. and Simões, M.G., Eds., Integration of Alternative Sources of Energy, John Wiley \& Sons, Hoboken, 379-418.

https://doi.org/10.1002/0471755621.ch15

[19] Lilienthal, P.D., Lambert, T.W. and Gilman, P. (2004) Computer Modeling of Renewable Power Systems. In: Cleveland, C.J., Ed., Encyclopedia of Energy, Elsevier, Amsterdam, Vol. 1, NREL Report CH-710-36771, 633-647.

https://doi.org/10.1016/B0-12-176480-X/00522-2

[20] Connolly, D., Lund, H., Mathiesen, B.V. and Leahy, M. (2010) A Review of Computer Tools for Analyzing the Integration of Renewable Energy into Various Energy Systems. Applied Energy, 87, 1059-1082. https://doi.org/10.1016/j.apenergy.2009.09.026

[21] IRENA International Renewable Energy Agency (2012) Renewable Energy Technologies: Cost Analysis Series-Hydropower. 
[22] Braciani, U. (2011) Cost Structure for Implementation of Power Generation Plants in Brazil. Graduation Work, Faculdade de Economia, Universidade Federal de Santa Catarina, Florianópolis. (In Portuguese)

[23] CEEE Companhia Estadual de Energia Elétrica (State Electric Energy Company) (2016) Series of Instantaneous Fow Data Discharged by the Canastra Power Plant throughout 2015, Personal Communication. Porto Alegre. (In Portuguese)

[24] ANEEL, Agência Nacional de Energia Elétrica (National Electric Energy Agency) (2008) Atlas of Electric Energy in Brazil. 3rd Edition, ANEEL, Brasília. (In Portuguese) http://www.aneel.gov.br/arquivos/PDF/atlas3ed.pdf 